\title{
Diversification, bank performance and risk: have Tunisian banks adopted the new business model?
}

\author{
Helmi Hamdi ${ }^{*}$, Abdelaziz Hakimi ${ }^{2}$ and Khemais Zaghdoudi ${ }^{2}$
}

\author{
* Correspondence: \\ helmi_aix@yahoo.fr \\ ${ }^{1}$ Aix-Marseille University CERGAM \\ (4225), Marseille, France \\ Full list of author information is \\ available at the end of the article
}

\begin{abstract}
Background: The objective of this paper is threefold. First, we test the most important factors that determine the level of non-interest income for Tunisian banks. Second, we study the impact of non-interest income on banks' profitability measured by both return on assets (ROA) and return on equity (ROE). Finally, we investigate the relationship between non-interest income and the level of risk taking.

Methods: To achieve this goal, we used annual data of 20 Tunisian banks during the period 2005-2012. In the empirical section we performed a Dynamic Panel Data model.

Results: Empirical results indicate that the main determinants of non-interest income are: relative performance (RROA and RROE), bank size, loan specialization and new epayments channels, automatic teller machine (ATM) and credit cards). We also find that diversification increases bank performance for both ROA and ROE measures. Eventually, non-interest income appears to be negatively and significantly correlated with the effect on the level of risk.

Conclusions: Tunisian banks are invited to more diversify their activities and do not focus only on the traditional activity. The noninterest income seems to be associated with a higher level of profitability and a lower risk.
\end{abstract}

\section{Background}

The determinants of bank profitability and performance have been studied since the seventies, following the seminal works by Short (1979) and later by Bourke (1989). These authors considered bank specific characteristics, industry specific factors and macroeconomic variables as the main determinants of bank profitability. Since then, a huge number of studies have been carried out on this issue (Pasiouras and Kosmidou (2007) and García-Herrero et al. (2009), Berger and Bouwman (2013), Berger and Bouwman (2013), Soedarmono, et al. (2013), Marozva (2015)). However, since the information and communication technological (ICT) revolution of the mid-nineties, non-traditional activities have become an additional contributor to bank revenues and have also become an important factor that determines bank performance and risk taking.

Literature on the impact of non-traditional activities on bank performance has provided a conflicting recommendation. In fact, while an important number of studies

(c) The Author(s). 2017 Open Access This article is distributed under the terms of the Creative Commons Attribution 4.0 International License (http://creativecommons.org/licenses/by/4.0/), which permits unrestricted use, distribution, and reproduction in any medium, provided you give appropriate credit to the original author(s) and the source, provide a link to the Creative Commons license, and indicate if changes were made. 
reported the positive impact of non-interest income (NII henceforth) on returns and risks (Ismail et al. (2015), Trivedi (2015), Lee et al. (2014), Meslier et al. (2014) and Saunders et al. (2014)), some other papers have found that traditional activities are considered as a key factor for more profitability and less risk (Pringle's (1974), Graddy and Kyle (1979), Molyneux et al. (1998), Ramadan et al. (2011), Carbó-Valverde et al. (2011) and Ekpu and Paloni (2015)). These conclusions show that the effects of non-interest income differ from one country to another one. For example, in the U.S, the average bank's fees and noninterest income represent $27 \%$ of net operating income while trading income counts for about 3.5\% (Stiroh, 2004a, b). In the same context, the ratio of NII moved from $25 \%$ to over $40 \%$ of their aggregate income over the period 1984 to 2001 (DeYoung and Roland, 2001a, b). In Europe, over the period 1996-2002, the average NII represented $23.16 \%$ of net operating income and $9.7 \%$ from trading income (Lepetit et al. 2008). In Italy, net interest income as a percentage of total assets fell from 3\% in 1993 to $1.8 \%$ in 2003 while non-interest income grew from 1\% to 1.4\% (Chiorazzo et al. 2008)). In Australia, the average net interest margin during the period 19872004 was around $2.236 \%$ whereas the NII was $1.835 \%$ (Williams and Prather 2010). In India, the contribution of interest income (IIC) in total income dominates the NII since the average IIC as a percentage of total income was $86.40 \%$ during the period 20052011, while NII represents only 13.60 (Trivedi 2015).

Given these inconsistencies, this research paper aims to analyze the weight and effects of non-interest income on overall bank performance within the Tunisian context. Tunisia is an interesting case study since it has witnessed extensive financial reforms in the beginning of 1990s such as implementation of the structural adjustment programs, trade liberalization and the ratification of many accords and trade agreements (Hamdi 2013). All these reforms aim to modernize the banking activities and to improve the financial service products. In this paper, we analyze the main factors that determine the level of non-interest income for Tunisian banks then, we study the impact of non-interest income on the banking profitability and finally, we explore the association between non-interest income and the level of risk taking. To the best of our knowledge, there is no study yet that has analyzed the impact of diversification on bank performance and risk within the Tunisian context. Therefore, this paper tries to fill the gap of literature by providing a comprehensive study. In the empirical study, we used annual data related to 20 Tunisian banks during the period 2005-2015 and we conduct an econometric model based on the General Moments of Methods in system (SGMM). Empirical results indicate that the main determinants of non-interest income are relatives' performance such as RROA and RROE, some bank specifics (bank size and loan specialization), technological innovation (ATM) and credit cards. We also find that diversification increases bank performance for both ROA and ROE measures. For the effect on the level of risk, non-interest income appears to be negatively and significantly correlated with the standard deviation SHROA and SHROE.

The structure of this paper is presented as follows. In section 2, we present the literature review. Section 3 provides an overview of the Tunisian banking. In section 4, we present a comparison of the importance of non-interest income and interest income. The section 5 provides data and methodology. Section 6 discusses the findings and section 7 concludes. 


\section{Non-interest income: A review of literature}

In this literature review we start by presenting the determinants of noninterest income then, we review the association between noninterest income and bank performance and finally, we analyze how noninterest income can make banks more risky.

\section{The determinants of noninterest income}

During the last two decades, banking sector has witnessed a structural change thanks to the financial deregulation and the rapid surge in information and communications technology in the financial markets. As a response to these competitive pressures that leads to low interest margin and weak profitability, many banks embraced the new business model based on the new banking activities. Empirically, many studies have been done using bloc of countries or single country to analyze the added value of noninterest income on bank profitability and performance. For example in Barbados, Craigwell and Maxwell (2006) studied the determinants of non-interest income and its impact on commercial bank financial performance. The authors have used a sample of commercial banks in Barbados between 1985 and 2001. Their results support that bank characteristics and the ATM technology as the most influential factors shaping the trend of non-interest income in the banking industry in Barbados. Findings also indicate that non-interest income is positively related to both bank profitability and earnings volatility.

Hakimi et al. (2012) analyzed the determinants of the noninterest income for the Tunisian context by the use of data of 10 Tunisian retail banks. The sample is observed during the period 1998-2009. Results of panel data regression reveal that the advance of information and communication technologies (ICT) proxied by the number of automatic teller machine and the number of credit cards affect positively the level of NII. Findings also indicate that banking characteristics such as the bank size, the credit quality and the banking strategy are considered as the main influential factors shaping the tendency of non-interest income in Tunisia.

Using a dataset of 662 relatively large commercial banks in 29 OECD countries during the period 1992 to 2006, Hahm (2008) analyzed the determinants and consequences of the NII. Empirical results show that banks with relatively large asset sizes, low net interest margins, high impaired loan ratios, and high cost-income ratios tend to exhibit higher non-interest income shares. Besides bank specifics the author tested the effect of macroeconomic factors on the level of NII. Findings indicate that banks showing slow economic growth, a stable inflation environment, and well developed stock markets tend to show higher non-interest income shares.

De Young and Hunter (2003) and De Young et al. (2004) also report that bank size is positively associated with the level of non-interest income. According to these authors, relatively large banks make use of economies of scale in order to dominate the production of consumer loans.

\section{Noninterest income and bank performance}

Recently, bank profitability was studied in association to bank specifics variables such as credit risk, liquidity risk, bank size and bank capital and industry specifics factors such as bank competition and concentration indexes.

Tan (2016) tested the impact of risk and competition on bank profitability. To this end, he used a sample of Chinese banking industry observed during the period 2003- 
2011. Generalized Method of Moments (GMM) system estimator was used as empirical approach. Findings indicate that there is no significant association between competition, risk and bank profitability. However, results show that Chinese bank profitability is affected by taxation, overhead cost, labour productivity and inflation.

In another recent study, Tan et al. (2017) used a sample of 100 Chinese commercial banks over the period 2003-2013 to investigate the determinants of bank profitability in China. The authors focused especially on the impact of efficiency, risk and competition on bank profitability. Empirical results reveal that under a lower competitive environment and weak bank risks, Chinese commercial banks records higher profitability.

In the same context, Tan and Anchor (2017) investigated the impact of competition on the main baking risks such as credit risk, liquidity risk, capital risk and insolvency risk. They used a sample of Chinese banking industry during the period 2003-2013 and he performed the Generalized Method of Moments (GMM) system estimator to examine the impact of competition on risk. Empirical findings showed that greater competition increases credit risk, liquidity risk, capital risk but decreases insolvency risk.

Literature on the effect of banking diversification has provided conflicting results on the real impact on non-interest revenues on banking profitability. Empirically, many studies found that diversification improved the level of performance and increased overall bank income. For example, Meslier et al. (2014) used a sample of 39 universal and commercial banks in the Philippines from1999 to 2005 to investigate the added value of banking diversification. Results indicate that noninterest income increases bank profits and also riskadjusted profits. In the same line of idea, Lee et al. (2014) investigated the effect of non interest income on bank profitability and risk using bank data of 22 countries in Asia and 967 individual banks over the period 1995-2009. By performing the dynamic panel Generalized Method of Moment method (GMM), results indicate that non-interest activities of Asian banks reduce risk, but do not increase profitability.

More recently, Sun et al. (2017) have used a dataset of 16 listed Chinese commercial banks, over the period of 2007 to 2013 to test the effect of noninterest income on the bank performance. By performing panel threshold model, empirical findings indicate that that there is a nonlinear relationship between noninterest income and bank performance. Findings also indicate that there is a negative association between the noninterest income ratio and performance of commercial banks. The authors reported that it should raise the ratio of noninterest income to a certain level to make banks more profitable.

Ismail et al. (2015) used a sample of Pakistani Banks for the period of 2006-2013 to explore the relationship between income diversification and banking performance. Findings showed a positive impact of income diversification on the level of bank in Pakistan. Similarly, Trivedi (2015) used a sample of 81 banks in India over the period 2005-2012. Major findings indicate that the rising share of fee-based income and non-interest income in total income and diversification has a positive impact on profitability.

For the U.S context, Saunders et al. (2014) used 368,006 quarterly observations on 10,341 U.S banks during the period 2002-2013, and found that a higher ratio of non interest income is associated with a higher profitability across the banking sector and under different market regimes. This result reported that stronger diversification might be the best alternative. In the same line of analysis, Craigwell and 
Maxwell (2006) employed quarterly data related to seven commercial banks in Barbados during the period from 1985 to 2001. Their findings confirmed that an increase in non-interest income is linked to greater bank profitability but also to higher earnings volatility.

\section{Noninterest income and bank risks}

Many studies have found that non-interest income derived from diversification of bank activities increases the bank risk. For example, Delpachitra and Lester (2013) used a sample of nine Australian-owned banks out of the twelve listed banks for the period 2000-2009 to study the effects of diversification of bank performance. Empirical results suggest that non interest income and revenue diversifications reduced profitability and did not improve the overall default risk of banks. They have concluded that non-interest income activities would not benefit banks. In another study, Williams and Prather (2010) focused on the effect of noninterest income on the bank risk-return. To this end, they have used 49 banks in Australia, which account for over $65 \%$ of Australian resident banking assets. As major findings, feebased income seems to be riskier than margin income but offers diversification benefits to bank shareholders.

The European context was explored by Chiorazzo et al. (2008). Based on annual data related to Italian banks over the period 1993-2003, they analyzed the link between noninterest revenues and profitability. Findings indicate that income diversification increases risk-adjusted returns. Those results are in line with current studies on E.U banks, but do not support findings on the U.S. experience. In particular, they find that this relation is consistent with large banks. However, Small banks can profit from increasing noninterest income when they have very little non-interest income share to start with.

Khalid Mndeme (2015) investigated the impact of noninterest income on bank performance in an African county which is Tanzania. To reach this goal, he used a sample of 25 banks for the period from 2002 to 2012. Empirical results of the fixed effect model revealed that interest income has a positive impact on performance. However, findings indicate that noninterest income activities may adversely affect bank performance. The evolution of the banking environment as the improvement of technology, competition, and diversification might be the best alternative to raise the bank profit of Tanzanian banks.

Stiroh $(2004 a, b)$ found that noninterest income is associated with more volatile returns and lower risk-adjusted profits. In another study, Stiroh (2006a, b) investigated the determinants of bank risk for a sample of U.S banks observed during the period 1997-2004. Results indicate that components of noninterest income are particularly volatile activities. Similarly, DeYoung and Roland (2001a, b) showed that fee-based activities are associated with increased revenue volatility, higher leverage, and increased earnings volatility. Using a sample of commercial banking companies in 42 countries during the period of 1995-2002, Gorener and Choi analyzed the effect of noninterest income on the risk-performance. The authors have found that non-interest income is associated with riskier stock returns in commercial banking companies. They explained this association by the increased market and the systematic risk. 


\section{An overview of the Tunisian banking sector:}

Since its independence in 1956, Tunisia has adopted two major development strategies. Until 1985 the country opted for an inward looking development strategy based on the establishment of import-substituting industries to meet the needs of the local population for manufactured goods and to reduce the trade deficit. This model of economic development has been blocked by its own mechanisms, since most of the companies created have not been able to expand and achieve economies of scale. Homemade products are non-competitive. This aggravated the budget deficit and led the country to resort to external debt, which accounted for almost 60\% of GDP in 1986.

Faced with this economic crisis, the IMF and the World Bank proposed to Tunisia the implementation of a structural adjustment program in 1986. Since then, the country has undertaken structural reforms which have changed the Tunisian economy which became diversified and open to the outside. On average, over the period 19902015 , the growth rate of GDP and the inflation rate are respectively $4.02 \%$ and $4.22 \%$, despite the difficult and unstable international situation. The budget deficit did not exceed $3 \%$ on average. In particular, the budget deficit has improved from $5 \%$ of GDP in

2014 to $4.8 \%$ in 2015 . $^{1}$ These performances of the Tunisian economy are realized thanks to the positive effects of the reforms that give considerable importance to the banking sector, which is constantly reformed to support economic growth.

The Tunisian banking sector has undergone significant structural reforms over the past three decades.

In December 1987, the Central bank of Tunisia (CBT, henceforth) has changed the rules for granting, monitoring and refinancing loans (circular ${ }^{\circ} 87-47$ of 12/23/1987) to give the financial institutions more importance in the Tunisian economy.

In 1988, the first Tunisian investment company (CSI) was born to promote the investment activities in the countries and to improve the Tunisian infrastructure. In 1992, the CBT launched several reforms aimed to improve the supervision of the banking sector and to remove a variety of restrictions on participation in the sector and the nature of products and services that could be provided. In 1994, the banking act $n^{\circ} 94-$ 25 of 02/07/1994 gave new options for development banks and deposit banks concerning their lending activities. This reform focuses on the liberalization of deposit interest rate, which aims to increase the competition between the two institutions.

The privatization of the public banks in 1997 leads to the increase of the level of competition between banks, and financial services were improved considerably. In 2001, a new banking act was born suggesting the generalization of the so-called universal bank instead of the specialized banks. This new reform allows banks to widen their expertise and to exercise new financial activities.

In 2005, the organization of the Tunisian banking sector has known three major events: first the creation of a new bank called "Banks of Financing of Small and medium-sized firms", second the privatization of the "Banque de Sud" which gives birth to "Attijari Bank" and third, the change of the statute of some development banks (STUSID, BTL, TQB and BTK) to universal banks. In January 2008 and within the framework of the program of restructuration of the banking system, there was the privatization of the "Tuniso-Koweitienne Bank" by the transfer of $60 \%$ of its capital to the profit of financial company «OCEOR», a subsidiary of the French group "Caisse d'Epargne". 
Headed by the Central Bank of Tunisia, the Tunisian banking sector is composed of credit institutions and offshore banks. Credit institutions include banks and financial institutions. $^{2}$

In 2015, Tunisia banking sector is made up of 23 banks: 11 of them are listed banks ${ }^{3}$ and they are the main players of the Tunisian stock exchange and the other are unlisted banks ${ }^{4}$ in which 3 of them are Islamic banks, which have been enriching the Tunisian banking landscape in recent years, by offering financial products that respect the principles of Islam.

As for financial institutions, they are made up of leasing institutions, factoring companies and business banks. In 2015, we had eight leasing establishments: Tunisia Leasing, International Leasing Company, Arab Tunisian Lease, Attijari Leasing, Modern Leasing, Arab International Lease, Best Lease and Hannibal Lease. Concerning factoring companies, there are two, which are Tunisia Factoring and Uni-Factor. Similarly, we had two business banks which are International Maghreb Merchant Bank and Business Bank of Tunisia. In addition to credit institutions, Tunisian banking sector includes also offshore banks. We had seven banks: Citibank, Tunisian Foreign Bank, Tunis International Bank, Loan and Investment Company, North Africa International Bank, Alubaf International Bank and Arab Banking Corporation.

In all development strategies adopted by Tunisia, Tunisian banks played a crucial role in financing the national economy. Even after the 2011 revolution, which caused a significant tightening of their liquidity, banks continued to fulfill their funding mission. The loans granted by these banks represented $81.65 \%$ of their total assets and $71.24 \%$ of GDP in 2015. The loans granted to businesses and professionals account for $71.78 \%$ of total outstanding loans to the economy, compared with $28.22 \%$ for loans to individuals. Concerning the time horizon, outstanding medium- and long-term loans represent $57.26 \%$ of total outstanding loans to the economy, compared with $42.74 \%$ for short-term loans. ${ }^{5}$

The Tunisian banking sector, which has long been involved in economic activity and has not in many cases been interested in its own requirements, suffers from several weaknesses, mainly its low profitability, the deterioration of the quality of its assets, poor governance, etc.

In 2015, the returns on assets (ROA) and the returns on equity (ROE) of Tunisian banks were respectively $1.06 \%$ and $11.07 \%$. Recently, the quality of assets of the Tunisian banking sector has been enormously deteriorated. Bank nonperforming loans to total gross loans are steadily increasing from $11.3 \%$ in 2011 to $14.5 \%$ in $2015{ }^{6}$ This deterioration is mainly due to the lack of effective supervisory instruments and rigorous prudential regulation. The majority of all Tunisian banks are small, even compared to banks in African countries. Total assets of all banks is TND 74589.359 million. $^{7}$ Total equity is TND 6484.61 million Tunisian dinars ${ }^{8}$ showing their low capitalization, as their capital adequacy ratio is $8.69 \%$. Furthermore, the structure of net banking income ${ }^{9}$ shows the significant weight of the interest margin (which represented 54.7\% of net banking income in 2015) compared to the commission margin (which represented 22.5\%). Tunisian banks continue to rely on traditional balance sheet intermediation activities, despite reforms to encourage banks to develop market activities and provide more personalized services to customers. The Tunisian banking sector is also characterized by the deterioration of its exploitation 
coefficient. ${ }^{10}$ In 2015, operating expenses accounted for $49.1 \%^{11}$ of net banking income. This high level of expenses is explained by the increase of staff costs, which rose from TND 811.4 million in 2011 to TND 1155.1 million in $2015 .^{12}$

All these weaknesses, non-exclusive of others, should not hide the strengths of the Tunisian banking sector. In fact, Tunisian banks continue to maintain longterm relationships with their customers, who remain loyal to their banks, despite the emergence of new banking service providers. Customer deposits did not fall even during and after the popular revolution of January 2011. They were valued in 2015 at 59556.580 Million Tunisian dinars ${ }^{13}$ against $60,905.717$ Million Tunisian dinars $^{14}$ for the credits granted; representing a coverage rate of $97.78 \%$. Tunisian Banks did not know the problem of the race of depositors to branch offices to withdraw their deposits. The risk of bank runs did not raise an issue for Tunisian banking sector, which has not suffered from global liquidity crisis. Tunisian banks invest heavily in new information and communication technologies. They can now follow their customers around the world without limiting themselves to national borders and without fear of time zones. The three main productivity ratios of $\mathrm{Tu}$ nisian banks evolved positively even after the revolution. Customer loans compared to the number of employees increased from 2191.8 Thousand Tunisian dinars in 2011 to 2617.5 Thousand Tunisian dinars in 2015. Customer deposits divided to the number of employees rose from 2050.1 Thousand Tunisian dinars in 2011 to 2544.1 Thousand Tunisian dinars in 2015. Net banking income relative to the number of employees moved from 110.2 Thousand Tunisian dinars in 2011 to 151.1 Thousand Tunisian dinars in 2015. ${ }^{15}$

To ensure their sustainability in an open and highly competitive environment, Tunisian banks are required to invest more in new technologies, to rely on highly qualified staff and to revise the primacy given to credit and deposit activities. They must develop market activities and provide diversified and personalized services to customers everywhere.

The Table 1 below indicates some main indicators of the Tunisian banking sector during the recent period 2010-2015. These indicators are relative to the ten (10) dynamic banks in Tunisia with regard to total assets, total deposit, total credit and also in term in financing the Tunisian economy.

\section{Interest income versus noninterest income in the Tunisian context}

The examination of the two Figs. 1 and 2 below reveals that the contribution of interest income (IC) is higher than that of non-interest income (NII). On average, the IC represents almost $4.5 \%$ in total assets and $70 \%$ in total gross revenue. However, the contribution of NII is very weak as it only represents almost $0.9 \%$ in total assets and $13 \%$ in total gross revenue. Those values indicate that Tunisian banks are concentrated on traditional activities: based on lending and deposit. On the contrary, the weak contribution of NII confirms that Tunisian banks are not oriented to diversified activities.

Table 2 shows also downward trends of NII and IIC during the period 2005-2012. For example, the ratio of NII as a share of total assets shifted from $1.039 \%$ in 2005 to $0.635 \%$ in 2012 . Also, the ratio of NII as compared to total gross revenue recorded the 
Table 1 Key indicators ${ }^{a}$ of the Tunisian banking sector

\begin{tabular}{lllllll}
\hline Indicators & 2010 & 2011 & 2012 & 2013 & 2014 & 2015 \\
\hline Profitability & & & & & & \\
ROA in (\%) & 1 & 0.74 & 2.5 & 2.14 & 1.08 & 1.06 \\
ROE in (\%) & 11.88 & 9.09 & 11.26 & 18.25 & 15.63 & 11.07 \\
NIM in (\%) & 2.4 & 2.27 & 2.35 & 1.64 & 2.52 & 2.27 \\
Competition/concentration & & & & & & \\
IHH in (\%) & 9.37 & 9.26 & 8.96 & 9.12 & 9.01 & 9.03 \\
Risk & & & & & & \\
LR in (\%) & 106.36 & 102.42 & 109.58 & 107.35 & 101.05 & 103.09 \\
CR in (\%) & 85.81 & 82.69 & 85.72 & 85.35 & 83.34 & 79.41 \\
Stability & & & & & & \\
Z-score (ROA) in (\%) & 6.44 & 6.12 & 6.03 & 5.41 & 5.94 & 6.36 \\
Z-score (ROE) in (\%) & 3.25 & 3.19 & 3.16 & 3.05 & 3.09 & 3.17 \\
IBS[1] & 0.5 & 0.45 & 0.43 & 0.39 & 0.47 & 0.44 \\
\hline
\end{tabular}

Source: The authors' calculation from annual reports of Central Bank of Tunisia and Professional Association of Tunisian Banks ${ }^{a}$ These indicators are calculated based on the average values for a sample of the most dynamics 10 Tunisian banks

same trend as it crossed from $14.506 \%$ in 2005 to $11.494 \%$ in 2012. Similarly, the evolution of the IIC as a share of total assets curve showed the same downward trend as it was $4.803 \%$ in 2005 and became $3.754 \%$ in 2012. In contrary, the report of IIC to gross revenue registered an upward trend. Hence, this ration moved from $65.8 \%$ in 2005 to reach $73.4 \%$ in 2012.

During the period of study 2005-2012, the average value of IIC and NII recorded some fluctuations. In fact, the average maximum values of NII are $1.077 \%$ and $14.506 \%$ with regard respectively to total assets and gross revenue. However, the average minimum value of NII divided by total assets, registered in 2012, is $0.635 \%$. The weak value of NII to total gross revenue, recorded also in 2012, represents only $11.494 \%$.

With regard to the contribution of IIC in total assets and gross revenue, statistics below indicate that the contribution of IIC to total gross revenue is very important. We have recorded $74.1 \%$ as a maximum value and $65.8 \%$ as a minimum value. Those levels

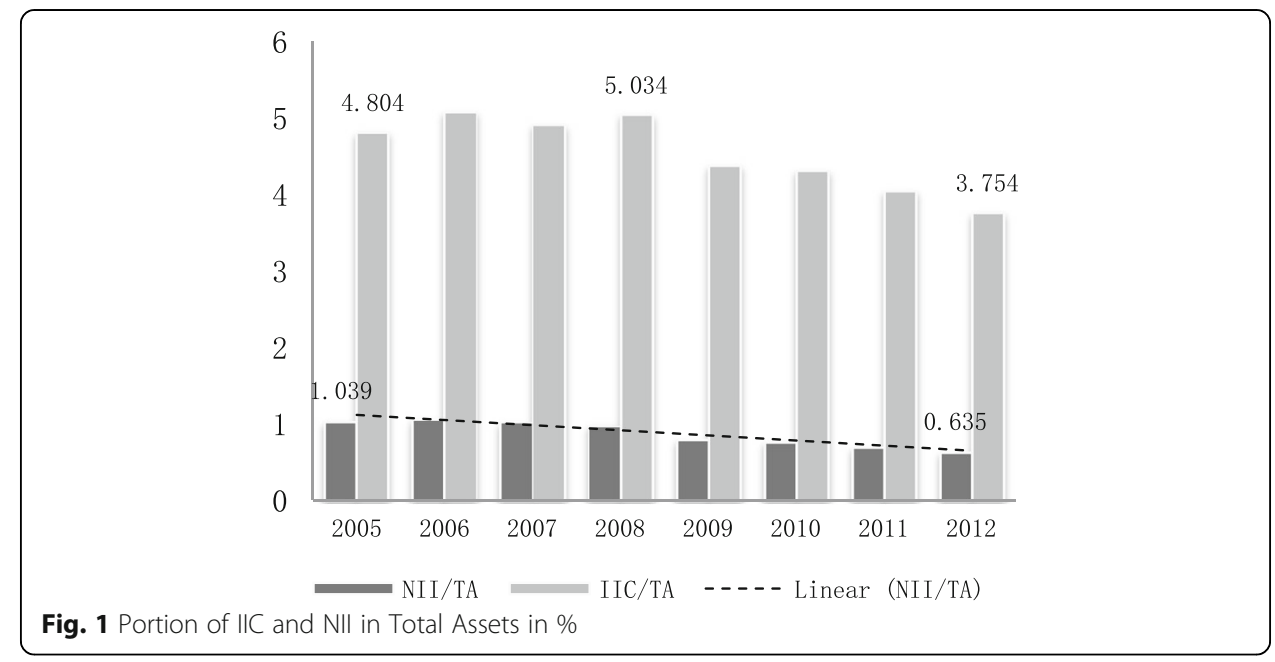




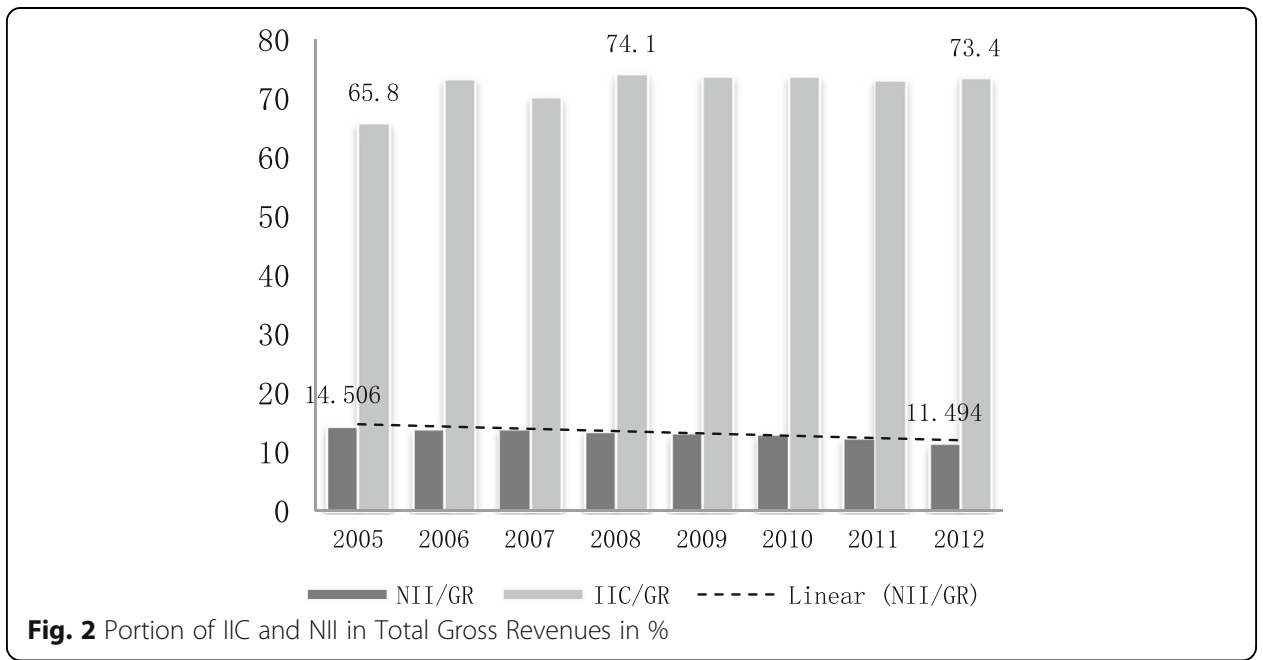

confirm the importance of the IIC in the total revenue of Tunisian banks since it represents almost 70\% of total revenue. Similarly, and taking into account the importance of the total assets value, we find that IIC represents $5.077 \%$ as a maximum value and $3.754 \%$ as a minimum value.

From all these statistics and data, we can conclude that Tunisian banks are more oriented to traditional activities such as business lending rather than diversified activities. Compared to other countries where the interest rate is very low, the Tunisian central bank and Tunisian banks suggest a high level of interest rate to their customers. For example, the monetary market rate was $4.87 \%$ in 2010 and 3.98\% in 2012. Also, the central bank's policy rate was 4.5\% in 2010 and $4.75 \%$ in 2012.

\section{Methods}

\section{Data and methodology}

The empirical section is done upon three steps: the first one is to study the determinants of non-interest income in Tunisia. We follow the previous studies initially developed by De Young and Rice (2004) and Stiroh (2004a, b) on the determinants of non-interest income by estimating the following model (1):

Table 2 Evolution of the average ROA, ROE, NII and IIC (Value are in \%)

\begin{tabular}{lllllll}
\hline Years & ROA & ROE & NII/TA & IIC/TA & NII/GR & IIC/GR \\
\hline 2005 & 0.215 & -2.283 & 1.039 & 4.804 & 14.506 & 65.800 \\
2006 & 0.535 & -3.559 & 1.077 & 5.077 & 14.007 & 73.300 \\
2007 & 0.716 & 5.907 & 1.028 & 4.903 & 14.031 & 70.100 \\
2008 & 1.087 & 9.071 & 0.979 & 5.034 & 13.620 & 74.100 \\
2009 & 0.897 & 7.902 & 0.799 & 4.377 & 13.233 & 73.800 \\
2010 & -1.886 & 13.138 & 0.773 & 4.306 & 13.037 & 73.800 \\
2011 & -0.187 & 5.528 & 0.708 & 4.039 & 12.370 & 73.100 \\
2012 & -0.162 & 4.629 & 0.635 & 3.754 & 11.494 & 73.400 \\
\hline
\end{tabular}

Source: The authors from annual reports of Tunisian banks Notes: ROA: return on assets, ROE: return on equity, NII: non-interest income, TA: total assets, GR: gross revenues, IIC: interest income 


$$
\begin{aligned}
& N I I_{i, t}=\alpha_{0}+\alpha_{1} N I I_{i, t-1}+\alpha_{2} R R O A_{i, t}\left(R R O E_{i, t}\right)+\alpha_{3} \operatorname{Size}_{i, t}+\alpha_{4} L R_{i, t}+\alpha_{5} L S_{i, t} \\
& +\alpha_{6} C_{A P R_{i, t}}+\alpha_{7} C_{i, t}+\alpha_{8} H H I_{i, t}+\alpha_{9} A_{T M} M_{i, t}+\alpha_{10} C A R D S_{i, t} \\
& +\alpha_{11} G D P_{i, t}+\alpha_{12} \operatorname{Inf}_{i, t}+\varepsilon_{i, t}
\end{aligned}
$$

The dependent variable is the total non-interest income (NII) as a share of total assets. This variable includes revenues from commissions plus other net noninterest income. RROA and RROE are the relative return on assets and relative return on equity that capture the bank performance. LR denotes liquidity risk. A high ratio of liquidity risk decreases NII. Banks with insufficient liquidity cannot response all partial or integral request of capital withdraw capital. This situation forces customers to search other sources more stable which negatively affect interest and indirectly non-interest income. CAPR is the capital adequacy ratio. A high capitalization indicates on high solvability which pushed banks to develop new activities and adopt new business model able to increase the level of NII. Consequently, we expected a positive association between CAPR and NII. LS is the lending specialization. An increase of this ratio confirms the orientation of banks toward traditional activities based on the interest income. So, the expected sign between these two variables is negative (Hahm (2008)). CD is the cost of deposit. Credit and deposit are the basis traditional banking activities. Also, an increase of this variable decreases the level of NII (Hahm (2008)). Size refers to the size of the individual bank relative to the total banking system. Banks with big size have the possibility to develop others non-traditional activities which are generator of NII. A positive association between bank size and the NII is expected (De Young and Hunter (2003), De Young et al. (2004)). For the macroeconomic variables we introduced GDP which is the real GDP per capita growth and INF which is inflation rate. The level of NII increases with a high level of growth and decreases with high level of inflation (Hakimi et al. (2012),. We also introduced the number of automated teller machines (ATMs) and the number of payments with cards (CARDS) as technological innovations proposed by Tunisian banks to promote and diversify their revenues. It is acknowledged that the use of ATM and Cards generate additional revenues to banks as commissions and fees. These two variables are considered as the basic component of the NII. Consequently, and increase of the number of ATM and the number of credit cards increases the level of NII (Craigwell and Maxwell (2006), Hakimi et al. (2012). Therefore, we expected a positive association between NII, ATM and credit cards. $\varepsilon$ is the error term. The aim of including all these variables will help to get a comprehensive study on all the factors that affect positively or negatively diversification beside the basic bank specific determinants. The definitions and measures of all the variables as well as their sources are provided in Appendix 1.

The second step is to investigate the contribution of non-interest income in bank performance. To this end, the dependent variable becomes ROA and then ROE. Unlike eq. (1), Non-interest income becomes an explanatory variable and bank performance indicator is the dependent variable. The model (2) is expressed as follows: 
Table 3 Summary statistics

\begin{tabular}{llllll}
\hline Variable & Obs & Mean & Std. Dev. & Min & Max \\
\hline ROE & 220 & 0.114 & 0.784 & -1.765 & 0.9423 \\
ROA & 220 & 0.002 & 0.049 & -0.540 & 0.092 \\
CARDS & 220 & 14,506 & 0,412 & 13,766 & 15,094 \\
ATM & 220 & 7770 & 1069 & 6590 & 9466 \\
INF & 220 & 0,043 & 0,010 & 0,020 & 0,058 \\
GDP & 220 & 0,032 & 0,021 & $-0,019$ & 0,067 \\
HHI & 220 & 0,095 & 0,004 & 0,090 & 0,101 \\
CD & 220 & 0,052 & 0,080 & 0,000 & 0,669 \\
NII & 220 & 0,011 & 0,008 & 0,004 & 0,035 \\
CAPR & 220 & 0,117 & 0,442 & -4253 & 1740 \\
LS & 220 & 0,840 & 0,104 & 0,177 & 0,988 \\
LR & 220 & 1759 & 4107 & 0,136 & 47,348 \\
SIZE & 220 & 13,999 & 1388 & 9699 & 16,169 \\
SHROE & 220 & 0,280 & 0,720 & 0,006 & 3313 \\
SHROA & 220 & 0,023 & 0,041 & 0,001 & 0,192 \\
CRISIS & 220 & 0.625 & 0.485 & 0 & 1 \\
\hline
\end{tabular}

$$
\begin{aligned}
& R O A(R O E)_{i, t}=\alpha_{0}+\alpha_{1}(R O A(R O E))_{i, t-1}+\alpha_{2} \operatorname{Size}_{i, t}+\alpha_{3} L R_{i, t}+\alpha_{4} L S_{i, t}+\alpha_{5} C A P R_{i, t} \\
&+\alpha_{6} C_{i, t}+\alpha_{7} H H I_{i, t}+\alpha_{8} \text { NII }_{i, t}+\alpha_{9} G D P_{i, t}+\alpha_{10} \operatorname{Inf}_{i, t} \\
&+\alpha_{11} \text { CRISIS }_{i, t}+\varepsilon_{i, t}
\end{aligned}
$$

In eq. 2 , we added a dummy variable CRISIS equal to 0 before 2008 and 1 after that date to see the impact of the global financial crisis on the performance of Tunisian banks.

Finally we analyze whether non-interest income has become a source of risk or not. To do this, we calculated the standard deviation of ROA and ROE simultaneously and we conducted the following model (3):

$$
\begin{aligned}
\operatorname{SHROA}(\operatorname{SHROE})_{i, t}= & \alpha_{0}+{ }_{\alpha 1}(\operatorname{SHROA}(\operatorname{SHROE}))_{i, t-1}+\alpha_{2} \operatorname{Size}_{i, t}+\alpha_{3} L R_{i, t}+\alpha_{4} L S_{i, t} \\
& +\alpha_{5} \operatorname{CAP}_{i, t}+\alpha_{6} \mathrm{CD}_{i, t}+\alpha_{7} H H I_{i, t}+\alpha_{8} N I_{i, t}+\alpha_{9} G D P_{i, t} \\
& +{ }_{\alpha 10} \operatorname{Inf}_{i, t}+\alpha_{11} \text { CRISIS }+\varepsilon_{i, t}
\end{aligned}
$$

The data used in this study is related to 20 Tunisian banks observed during the period 2005-2015 and were extracted from their financial statements. Unlike the previous studies that used the seemingly unrelated regression estimation and Generalized Least Square regression, we employ in this paper the system Generalized Method of Moment (GMM) estimator in dynamic panel data models initially proposed by Arellano and Bover (1995) and later by Blundell and Bond (1998). Specifically, we use the GMM in system (SGMM) since it has been proved to improve the GMM estimator in the first differenced (DGMM) model in terms of bias and root mean squared error. According to Blundell and Bond (1998) the SGMM estimator provide more rational results than the DGMM estimator because the instruments in the Level model remain good predictors for the endogenous variables in this model even when the series are very persistent (Bun and Windmeijer, 2010). 
Table 4 Determinants of non-interest income

\begin{tabular}{|c|c|c|}
\hline & $\mathrm{NII}$ & $\mathrm{NII}$ \\
\hline \multirow[t]{2}{*}{ L.NII } & 0.287 & 0.271 \\
\hline & $(3.80)^{* * *}$ & $(3.90)^{* * *}$ \\
\hline \multirow[t]{2}{*}{$\mathrm{ROA}$} & 0.001 & - \\
\hline & $(1.29)$ & - \\
\hline \multirow[t]{2}{*}{ ROE } & - & 0.002 \\
\hline & - & $(0.82)$ \\
\hline \multirow[t]{2}{*}{ SIZE } & -0.003 & -0.002 \\
\hline & $(2.04)^{* *}$ & $(1.67)^{*}$ \\
\hline \multirow[t]{2}{*}{ LR } & -0.002 & -0.007 \\
\hline & $(1.89)^{*}$ & $(1.94)^{*}$ \\
\hline \multirow[t]{2}{*}{ LS } & -0.012 & -0.012 \\
\hline & $(2.57)^{* *}$ & $(2.73)^{* * *}$ \\
\hline \multirow[t]{2}{*}{ CAPR } & -0.001 & -0.001 \\
\hline & $(5.96)^{* * *}$ & $(2.13)^{* *}$ \\
\hline \multirow[t]{2}{*}{$C D$} & -0.015 & -0.016 \\
\hline & $(3.51)^{* * *}$ & $(3.82)^{* * *}$ \\
\hline \multirow[t]{2}{*}{$\mathrm{HHI}$} & 0.410 & 0.400 \\
\hline & $(6.21)^{* * *}$ & $(7.41)^{* * *}$ \\
\hline \multirow[t]{2}{*}{ ATM } & 0.005 & 0.004 \\
\hline & $(12.10)^{* * *}$ & $(12.57)^{* * *}$ \\
\hline \multirow[t]{2}{*}{ CARDS } & 0.001 & 0.021 \\
\hline & $(5.73)^{* *}$ & $(5.08)^{* *}$ \\
\hline \multirow[t]{2}{*}{ GDP } & 0.043 & 0.045 \\
\hline & $(2.08)^{* *}$ & $(2.24)^{* *}$ \\
\hline \multirow[t]{2}{*}{ INF } & 0.004 & -0.003 \\
\hline & $(0.58)$ & $(0.39)$ \\
\hline Wald chi2(12) & $26,189.88$ & 9907.80 \\
\hline Prob > chi2 & $0.0000^{* * *}$ & $0.0000^{* * *}$ \\
\hline Arellano-Bond Test for AR (1) & -1.8266 & -1.6324 \\
\hline p-value & $0.04981^{* *}$ & $0.0926^{*}$ \\
\hline Arellano-Bond Test for AR(2) & 0.44292 & 0.3555 \\
\hline$p$-value & 0.2641 & 0.7222 \\
\hline Sargan test & 13.1144 & 11.5157 \\
\hline$p$-value & 0.6987 & 0.4836 \\
\hline $\mathrm{N}$ & 200 & 200 \\
\hline
\end{tabular}

The validity of the instruments is tested using a Sargan test of over-identifying restrictions and a test of the absence of serial correlation of the residuals. The Sargan test has a null hypothesis of "the instruments as a group are exogenous". Therefore the higher the $p$ value of the Sargan statistic the better the results are.

Table 3 below summarizes the descriptive statistics of the variables used in this study. The most important conclusion to draw from Table 3 is the significant variation in ROE of the banks in the sample. 
The NII registered on average a value of $1.1 \%$ with a maximum of $3.5 \%$ and a minimum value of $0.4 \%$. These values indicate that Tunisian banks are based on traditional activities and they are not oriented to the diversification. The mean of ROE is $11.4 \%$ with a minimum of $-1.765 \%$ and a maximum of $94.23 \%$ reflecting a period of up and down in banking activities. As for average ROA, it appears low (0.2\%) during the selected period of study and similar conclusion is found for non-interest income. At a glance, it seems that the banking sector was not performing effectively during 2005-2015 or it was affected by several shocks such as the 2007 global financial crisis and the 2011 social unrest. This conclusion is confirmed when we see economic growth proxied by GDP moving from $-1.9 \%$ (minimum value) to $6.8 \%$ (maximum value). Also, the average rate of inflation was $4.3 \%$ and its maximum and minimum are respectively $5.8 \%$ and $2 \%$.

After giving descriptive information about all variables used in our study, we present in Appendix $2^{16}$ below the nature and the level of correlation between variable. The correlation matrix gives information if the correlation is negative or positive, weak or very high. In consequence, we can detect the presence or the absence of multicolenearity problem. From the Appendix 2, we conclude that the level of correlation between all variable is very weak which implies the absence of multicolenearity problem.

\section{Results}

\section{Determinants of non-interest income in Tunisia}

In the first step of this research, we estimate eq. 1 where RROA and RROE are introduced separately in the model. As we mentioned previously, we preferred conducting an S-GMM than a basic OLS since the later can provide spurious results because the presence of endogeneity in the previous shocks to the dependent variable $\left(N I I_{i . t}\right)$ can generate a correlation issue between its past observations $\left(N I I_{i . t-1}\right)$ and the error term that leads to a dynamic panel bias. Broadly, the Arellano and Bond test for autocorrelation has a null hypothesis of no autocorrelation and is applied to the differenced residuals. The test for AR (1) process in first differences usually rejects the null hypothesis. The test for AR (2) in first differences is more important because it will detect autocorrelation in levels. The use of a Sargan test of over-identifying restrictions is helpful to validate the instruments. The Sargan test has a null hypothesis of "the instruments as a group are exogenous". Therefore the higher the $p$-value of the Sargan statistic is the better the results are.

Table 4 below indicates that the p-value of 0.69 and 0.48 are high enough so that we cannot reject the joint hypothesis that the over identifying restrictions are valid. Therefore, we can conclude that our internal instruments are valid and not correlated with the residuals.

Overall, the output of both regressions shows identical results that could be summarized as follows. First, the size of the bank is negatively and significantly linked to noninterest income. For Tunisian banks, it seems that larger institutions have preference for traditional activities rather than adopting the new business model. In Tunisia, bank restructuring leading to an increase in the size of banks have not yielded the expected results. Also, large bank recognize a high level of asymmetric information problems associated with lending which can lead to high level of nonperforming loans. Our Results are in line with Barros et al. (2007), Athanasoglou et al., 2008) and different from the 
work of De Young and Hunter (2003) and De Young et al. (2004) which support the positive association between bank size and NII.

Empirical findings show that the relative performance of banks (RROA and RROE) is a factor that promotes diversification. When banks are profitable, they invest in new financial and technological innovations and integrate them into their business strategy. However, when banks are not resilient and their performance is weak, they prefer delaying their investment in diverse source of revenues (i.e. ICT). As a result, noninterest income will shrink.

Loan specialization (LS) as proxy of credit risk is found to be negatively and significantly associated with bank performance. This could be explained by the fact

Table 5 Non-interest income and bank performance

\begin{tabular}{|c|c|c|}
\hline & $\mathrm{ROA}$ & $\mathrm{ROE}$ \\
\hline \multirow[t]{2}{*}{ L.ROA } & 0.437 & - \\
\hline & $(1.85)^{*}$ & - \\
\hline \multirow[t]{2}{*}{ L.ROE } & - & 0.210 \\
\hline & _ & $(1.89)^{*}$ \\
\hline \multirow[t]{2}{*}{$\mathrm{NII}$} & 2.062 & 2.546 \\
\hline & $(3.54)^{* * *}$ & $(2.61)^{* * *}$ \\
\hline \multirow[t]{2}{*}{ SIZE } & -16.215 & 0.412 \\
\hline & $(2.15)^{* *}$ & $(0.13)$ \\
\hline \multirow[t]{2}{*}{$L R$} & -5.569 & -.583 \\
\hline & $(1.74)^{*}$ & $(2.22)^{* *}$ \\
\hline \multirow[t]{2}{*}{ LS } & 6.555 & -8.144 \\
\hline & $(0.17)$ & $(1.38)$ \\
\hline \multirow[t]{2}{*}{ CAPR } & 7.792 & 6.078 \\
\hline & $(2.84)^{* * *}$ & $(3.97)^{* * *}$ \\
\hline \multirow[t]{2}{*}{$C D$} & -3.409 & -8.709 \\
\hline & $(1.05)$ & $(1.95)^{*}$ \\
\hline \multirow[t]{2}{*}{$\mathrm{HHI}$} & 1.755 & 5.220 \\
\hline & $(1.29)$ & $(2.69)^{* * *}$ \\
\hline \multirow[t]{2}{*}{ GDP } & -3.896 & -5.407 \\
\hline & $(1.63)$ & $(5.60)^{* * *}$ \\
\hline \multirow[t]{2}{*}{ INF } & 2.357 & 2.696 \\
\hline & $(0.47)$ & $(2.40)^{* *}$ \\
\hline \multirow[t]{2}{*}{ CRISIS } & -30.937 & -32.060 \\
\hline & $(3.52)^{* * *}$ & $(3.86)^{* * *}$ \\
\hline Wald chi2(11) & 4926.45 & 960.16 \\
\hline Prob > chi2 & $0.0000^{* * *}$ & $0.0000^{* * *}$ \\
\hline$A B$ test for $A R(1)$ & -2.4873 & -2.4145 \\
\hline$p$-value & $0.0129^{* *}$ & $0.0158^{* *}$ \\
\hline$A B$ test for $A R(2)$ & .95865 & 0.3555 \\
\hline$p$-value & 0.3377 & 0.7222 \\
\hline Sargan test & 6.78367 & 11.5157 \\
\hline$p$-value & 0.6987 & 0.5836 \\
\hline $\mathrm{N}$ & 200 & 200 \\
\hline
\end{tabular}


that banks with a relatively large loan portfolio prefer to continue exercising the traditional activities rather than diversifying their revenues. This result differs from the finding of DeYoung and Roland (2001a, b). Also, we found that liquidity risk (LR) is negatively associated with the NII. An increase in the liquidity risk decreases the level of NII. Credit lines act as insurance for borrowers against liquidity shocks and the related fees can affect significantly the level of NII. An increase of liquidity risk decrease the bank reputation and it results a flight toward others investment with greater return (Berg et al. (2013)).

Turning now to technological innovation variables, ATM has a positive and significant impact on non-interest income suggesting that banks adopting ATMs have apparently higher level of NII. However, this effect is negligible. Similarly, it was found that CARDS acts positively and significantly to NII with a low coefficient. Here, it is obvious that technology has an important role in promoting banks 'revenues and we recommend that Tunisian financial institutions integrate technological innovations for many reasons: To follow the new business model in which Tunisian people are living (Internet, mobile phone, e-business, etc.) and to promote the widespread use of these financial and technological innovations at an affordable cost. Our results support the findings of Hakimi et al. (2012), Craigwell and Maxwell (2006).

Table 4 indicates that the HHI exerts a positive and significant effect on NII. The concentration level of the Tunisian banking sector is almost around $10 \%$. This implies that this sector tends to be classified as competitive one. Hence, banks should diversify their activities to attract more customers. Besides traditional activities, banks seek to engage in new business that generate and increase their noninterest income.

Finally, we can see from Table 4 that while inflation has no effect on non-interest income, GDP has a positive and an indirect significant impact. This conclusion reveals that when economic performance is flourishing the banking sector is also performing well and banks looks more for new opportunity to innovate and diversify their revenues. To conclude, a buoyant economic growth in Tunisia would support the performance of the banking sector and could provide opportunities to diversify bank revenues. These findings are different from the work of Hakimi et al. (2012) where inflation exerts a negative and significant effect however inflation do not has any significant effect. In theory, previous studies have reported a positive association between inflation and bank profitability. High inflation rates are generally associated with high loan interest rates. However, if inflation are not anticipated and banks are sluggish in adjusting their interest rates then there is a possibility that bank costs may increase faster than bank revenues and hence adversely affect bank profitability (Ben Naceur and Goaied (2008).

\section{Diversification and bank performance}

In this section, we estimate eq. 2 where profitability of Tunisian banks is measured by Return on Equity (ROE) and Return on Assets (ROA). The output of the model is displayed in Table 5 below.

This table shows the following results. First, profitability of banks increases with the increase of non-interest income. This is a very important conclusion which indicates the role of diversification in promoting banking profitability. Therefore, bankers 
have to realize the importance of investing in different channels other than the basic activities which have become obsolete in the current knowledge-based society. Banks should also adapt their strategy to the business cycle and the evolution of technology and the change in society. As stated by Schumpeter (1912), innovation is crucial in the process of economic development and the evolution of the society will lead to the destructive creation and the birth of new innovations. Therefore, we can conclude that diversification is a mechanism to boost profitability and operational efficiency particularly if the scale and scope of operations increase (Landskroner et al. (2005)). Higher ratio of non-interest income to interest income is associated with a higher profitability across the banking sector and under different market regimes. Also, bank with high non-interest income present lower risk than those with mainly interest income. Our results support the finding of Nguyen et al., (2015) and Saunders et al., (2014). However, these findings are different from the work of Hayden et al., (2007) and Stiroh (2006a, b).

Size appears to affect negatively and significantly only ROA. As measured by the logarithm of total assets, an increase in banking size is associated with a decrease of bank performance. The total asset of Tunisian banks is dominated by the credit activity. However, for some banks of our sample, these credits are not sufficiently provisioned. Consequently, it results a loss of the principal amount and the interest which lead to a decline of their performance. It was also found that capital adequacy ratio affected ROE and ROA of Tunisian banks positively and significantly. This result is in line with the findings of Ben Naceur and Goaied (2001), Kaya (2002), Barros et al. (2007) and Atasoy (2007).

Capital adequacy ratio (CAP) is positively and significantly at $1 \%$ of level of significance with bank performance. This means that an increase in bank capital increases significantly bank performance. Capital reflects the bank ability to support unexpected losses. Consequently, the strength and quality of capital will influence the level of bank performance. Also, banks with higher capital ratios tend to face lower costs of funding due to lower prospective bankruptcy costs. Our results confirm the work of Abreu and Mendes (2002), Goddard et al. (2004), Ben Naceur and Goaied (2008) and García-Herrero et al. (2009).

The Hirshmen Herfindahl index (HHI) acts positively and significantly at the level of $1 \%$ on the bank performance (ROE). In this study, banking concentration improves the performance of Tunisian banks. A concentrated banking system provides more stability (Boyd and De Nicoló 2005). On the contrary, in a competitive banking system, there is an increase of the risk taking behaviour. Banks can accept to finance risky projects with high expected returns but with a low probability of success. These speculative and risk-taking behaviours reduce bank performance (Beck et al. 2006)).

The liquidity risk (LR) is negatively and significantly correlated with bank performance. An increase in the liquidty risk is associated with a decrease of performance. Traditional bank activities are based on liquidity. Banks with insufficient liquidity may undergo a decline of income derived from loans activity. Consequently, the interest revenues decreased which leads to a decrease in the bank performance. Our results are in line with Cuong Ly (2015), Marozva (2015), Mamatzakis and Bermpei (2014). 
Table 6 Diversification and risk

\begin{tabular}{|c|c|c|}
\hline & SHROA & SHROE \\
\hline \multirow[t]{2}{*}{ L.SHROA } & 0.945 & - \\
\hline & $(7.16)^{* * *}$ & - \\
\hline \multirow[t]{2}{*}{ L.SHROE } & - & 0.753 \\
\hline & - & $(79.23)^{* * *}$ \\
\hline \multirow[t]{2}{*}{ SIZE } & 0.000 & -0.002 \\
\hline & $(0.05)$ & $(0.22)$ \\
\hline \multirow[t]{2}{*}{ LR } & -0.000 & -0.004 \\
\hline & $(0.76)$ & $(4.51)^{* * *}$ \\
\hline \multirow[t]{2}{*}{ LS } & 0.027 & 0.211 \\
\hline & $(1.03)$ & $(5.63)^{* * *}$ \\
\hline \multirow[t]{2}{*}{ CAPR } & 0.016 & 0.061 \\
\hline & $(4.13)^{* * *}$ & $(4.66)^{* * *}$ \\
\hline \multirow[t]{2}{*}{$C D$} & 0.016 & 0.326 \\
\hline & $(1.33)$ & $(4.17)^{* * *}$ \\
\hline \multirow[t]{2}{*}{$\mathrm{HHI}$} & -0.992 & -0.963 \\
\hline & $(2.62)^{* * *}$ & $(0.73)$ \\
\hline \multirow[t]{2}{*}{ GDP } & -0.062 & -0.250 \\
\hline & $(3.52)^{* * *}$ & $(3.09)^{* * *}$ \\
\hline \multirow[t]{2}{*}{ INF } & 0.007 & 0.067 \\
\hline & $(0.11)$ & $(0.13)$ \\
\hline \multirow[t]{2}{*}{$\mathrm{NII}$} & 0.153 & -1.943 \\
\hline & $(0.82)$ & $(2.16)^{* *}$ \\
\hline \multirow[t]{2}{*}{ CRISIS } & -0.008 & -0.030 \\
\hline & $(7.36)^{* * *}$ & $(1.77)^{*}$ \\
\hline Wald chi2(65) & $648,248.50$ & $69,907.80$ \\
\hline Prob > chi2 & $0.0000^{* * *}$ & $0.0000^{* * *}$ \\
\hline$A B$ test for $A R(1)$ & -1.5223 & -1.8824 \\
\hline$p$-value & $0.08021^{* *}$ & $0.0926^{*}$ \\
\hline$A B$ test for $A R(2)$ & 0.6211 & 0.6210 \\
\hline$p$-value & 0.2641 & 0.7222 \\
\hline Sargan test & 12.9043 & 11.5157 \\
\hline$p$-value & 0.8828 & 0.7591 \\
\hline N & 200 & 200 \\
\hline
\end{tabular}

As for macroeconomic factors, the GDP is shown to be negative and significant with the dependent variable (ROE). It is worth recalling that since 2010 Tunisia has witnessed the so called Arab Spring which is in realty a social upheaval against the political regime. The change was successful but with an extravagant cost for almost all the economic and financial sectors in the country including the banking sector. Therefore, we can conclude that the economic instability is the reason explaining the negative link between growth and banking performance. This result supports the one found by Nilsen and Rovelli (2001) that suggests that a weak macroeconomic environment will deter foreign investments, reverse capital flows and discourage financial innovation. 
We also find that inflation rate affect profitability ratios positively and significantly. This result could reveal the reality in Tunisia during the selected period where inflation was moderate during 2005-2010 and reached 5.13\% in 2012 and 5.79\% in 2013. Despite the high inflationary pressure, banks continue to realize high profit and inflation doesn't impact directly banking performance. This result is in line with the previous studies by Demirgüç-Kunt and Huizinga (1999). Kaya (2002). Jiang and Sze (2003) and Atasoy (2007).

The shock provoked by the global financial crisis proxied in this paper by CRISIS is in line with our analysis on the impact on GDP on ROA/ROE. The crisis simply deteriorated the banking and financial sector of almost all countries in the world and Tunisia was not saved. This result is in line with the work of Sufian and Shah Habibullah (2010).

\section{Non-interest income and risk}

To adjust the volatility of bank profitability, which indicates the risk behavior, we compute their standard deviation over the entire sample period. We define our indicators of bank performance as the ratio between the annual return and its standard deviation. Following Stiroh (2004b), we call these indexes Sharpe ratios (or risk-adjusted returns, SHROE and SHROA). The results of eq. 3 are displayed in Table 6 below.

Estimation results show that when NII increases, the standard deviation of the return on equity of Tunisian banks decreases and vice versa. Diversification, approximated by NII, alleviates the volatility of returns of banks and reduces their risks. This conclusion suggests that diversification is considered as a hedge against risk-adjusted return that reduces the probability of financial distress Froot and Stein (1998a, b). Therefore, as it is shown in the model, it is important to diversify activities to increase revenues in order to curb the adverse effects of financial distress. This finding is in line with the finding of Stiroh and Rumble (2006) and Stiroh (2004a, b) for the American context.

Liquidity risk is positively and significantly associated with the Sharpe ROE ratio. The transformation of deposits into loans destabilizes the financial profitability of banks and increases their risks. For this reason, Tunisian banks must downgrade the liquidity rate, which is on average 1.582. This disproportionate evolution between loans and deposits can lead to the deterioration of banks' liquidity. Our findings are in line with Cuong Ly (2015), Marozva (2015), Mamatzakis and Bermpei (2014).

According to the results found, the volatility of return on equity (SHROE) is due to the strong specialization of Tunisian banks, which rely heavily on lending activity, as the average specialization ratio (LS) is $83.9 \%$. To reduce banking risk, Tunisian banks must revise the primacy accorded to traditional balance sheet intermediation and diversify their activities.

For the capital adequacy ratio, it has a positive and a significant impact on both measures of bank risk SHROA and SHROE. As banks' equity increases, bank risk-taking also increases. In recent years, the commercial title portfolio and the investment portfolio of Tunisian banks have been diversified. This finding corroborates the work of Aggrawal and Jacques (2001). 
The volatility of return on equity (SHROE) and consequently banking risk is explained, among other things, by the costs of bank deposits, which are expensive for Tunisian banks. The average deposit cost is $5.2 \%$. This increase in banks' resources stems from the behavior of depositors who have become demanding in terms of remunerating their deposits. These depositors are requesting indexation of their rates on market rates.

Furthermore, the econometric results reveal also that the IHH concentration index acts negatively and significantly on the volatility of the return on assets and the risk of Tunisian banks. This result is explained by the structure of the Tunisian banking market, which tends towards a competitive structure, since the average HHI ratio is $9.7 \%$. Increased competition encourages banks to take risks and offer risky but high return products and services.

Concerning the international financial crisis, it increased the risk of the Tunisian banks, since the volatility of the economic and financial returns has increased. This result can be explained by the opening up of the Tunisian economy and the banking sector to the world economy and the synchronization of the economic cycles of Tunisia with those of Europe, which suffered greatly from this crisis.

As for macroeconomic variables, only the annual growth rate of GDP per capita has a negative and significant impact on the volatility of the returns on assets and equities of banks. This result shows that the economic environment, in which banks operate, although unstable especially after the popular revolution of 2011, has reduced bank risks.

\section{Conclusion}

The objective of this paper is to investigate the determinants of non-interest income in Tunisian banks and to test the effect of non-interest income on the risk-performance. To this end, we have used annual data related to 20 Tunisian banks during the period 2005-2015. The econometric method served in this paper is the dynamic panel data analysis; precisely we performed the GMM in system method. Empirical results indicate that main determinants of non-interest income are bank specifics such as bank size, liquidity risk, capital adequacy ratio and loan specialization. As for technological innovations proxied by ATM and credit cards, the results show that they are positively associated with NII and bank performance as well (ROA/ROE) but their coefficients are small. Here, it is obvious that technology has an important role in promoting banks 'revenues but we recommend Tunisia' bankers to integrate more technological innovations in their business activities and to introduce new financial service channels and products to their customers. Banks must follow the new business model in which Tunisian people are living (Internet, mobile phone, e-business, etc.) and to promote the widespread use of these financial and technological innovations at an affordable cost.

For the effect on the level of risk, non-interest income appears to be negatively and significantly correlated with the standard deviation SHROE. This conclusion suggests that diversification is important since it increases the bank revenue and also lower the probability of occurrence of a distress such as bank crisis.

As for macroeconomic factors, the GDP and inflation are shown to be positively correlated with the bank performance. This shows that in when the economy is thriving, banks have better performance and better results. 


\section{Appendix 1}

Table 7 Summary statistics and definitions of variables

\begin{tabular}{|c|c|c|c|c|}
\hline$\underline{\text { Variables }}$ & Definitions & Measures & Mean & Std Dev \\
\hline $\mathrm{ROE}$ & Return on assets & Net income / Total Assets & 0.114 & 0.784 \\
\hline $\mathrm{ROA}$ & Return on equity & Net income / Total Equity & 0.002 & 0.049 \\
\hline SHROA & Sharpe ratios $\mathrm{ROA}$ & Standard deviation of ROA & 0.023 & 0.041 \\
\hline SHROE & Sharpe ratios $\mathrm{ROE}$ & Standard deviation of ROE & 0.280 & 0.720 \\
\hline SIZE & Size & Logarithm of Total Assets & 13.999 & 1.388 \\
\hline$L R$ & liquidty risk & Total Loans / Total Deposit & 1.759 & 4.107 \\
\hline LS & Loans specialization & Total Loans / Total Assets & 0.840 & 0.104 \\
\hline CAPR & Capital ratio & Equity / Total Assets & 0.117 & 0.442 \\
\hline $\mathrm{NII}$ & Noninterest income & Noninterest income / Total assets & 0.011 & 0.008 \\
\hline$C D$ & Cost of deposit & Interest expenses / Total Deposit & 0.052 & 0.080 \\
\hline $\mathrm{HHI}$ & Index of Hirshmen Hirfendhal & Sum of squared market share (Assets) & 0.095 & 0.004 \\
\hline ATM & Number of ATMs & The logarithm of the number of ATMs & 7.770 & 1.069 \\
\hline CARD & Number of credit cards & The logarithm number of credit cards & 14.506 & 0.412 \\
\hline CRISIS & International financial crisis & Dummy variable equal 0 before 2008 and 1 after & 0.625 & 0.485 \\
\hline GDP & GDP per capita & Annual growth rate of GDP per capita & 0.032 & 0.021 \\
\hline INF & inflation rate & Customer index price & 0.043 & 0.010 \\
\hline
\end{tabular}




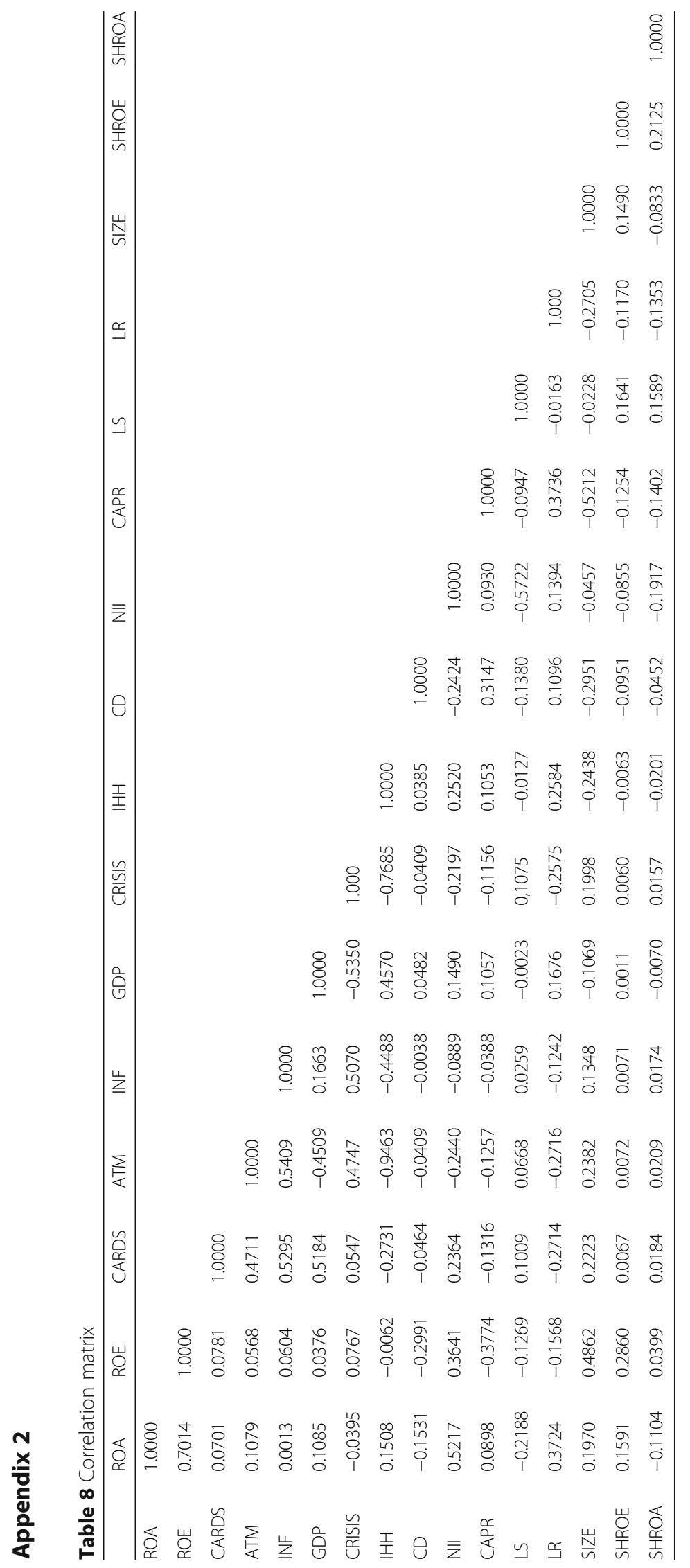


To conclude, Tunisia banks have well adopted the new business model based on the new financial innovations. However, the findings of this paper show that banks did not fully benefit yet from this new business model. The reasons could be related to: the cost of adoption of these innovations, the weak financial infrastructure in some regions of the country, the lack of information and the low level of Tunisian people financially included in the financial sector. Therefore, we encourage banks to diversify their activities by introducing new channels, new financials products and, also by lowering the costs of adoption of these innovations.

In this study, results indicate that NII is positively correlated with the bank performance and decrease significantly the level of risk. However, nothing has been said so far from which level NII can promote performance and decrease associated risk. Therefore, given the importance of this issue, we except to explore this problem in our forthcoming study by also expanding the time series to more than 11 years as it is done in this current paper. This could be done by employing for example the panel smooth transition regression model (PSTR) which is the proper tool that determine the optimal threshold of NII that might affect bank performance and risk.

\section{Endnotes}

${ }^{1}$ Annual Report of Professional Association of Tunisian Banks (2015), p.7.

${ }^{2}$ Financial Statistics of Central Bank of Tunisia, №191, July 2015.

${ }^{3}$ National Agricultural Bank, Tunisian bank Company and Housing Bank (public banks), Bank of Tunisia, Arab International Bank of Tunisia, Amen Bank, Arab Tunisian Bank, Attijari Bank, International Union of Banks, Banking Union for Trade and Industry and Bank of Tunisia and Emirates (private banks

${ }^{4}$ French-Tunisian Bank, Tunisian Solidarity Bank, Tunisian- Kuwaiti Bank, Stusid Bank, Qatar National Bank, Tunisian-Libyan Bank, Financing Bank of Small and Medium-sized Enterprises, Citibank, Arab Banking Corporation, Zitouna Bank, Al Baraka Bank Tunisia and El Wifack International Bank

${ }^{5}$ Annual Report of Professional Association of Tunisian Banks (2015), p.8.

${ }^{6}$ Percentage taken from the World Development Indicators database.

${ }^{7}$ Annual Report of Professional Association of Tunisian Banks (2015), p.37.

${ }^{8}$ Annual Report of Professional Association of Tunisian Banks (2015), p.37.

${ }^{9}$ Annual Report of Professional Association of Tunisian Banks (2015), p.12.

${ }^{10}$ This coefficient is equal to operating expenses divided by net banking income.

${ }^{11}$ Annual Report of Professional Association of Tunisian Banks (2015), p.13.

${ }^{12}$ Annual Report of Professional Association of Tunisian Banks (2015), p.12.

${ }^{13}$ Annual Report of Professional Association of Tunisian Banks (2015), p.37.

${ }^{14}$ Annual Report of Professional Association of Tunisian Banks (2015), p.37.

${ }^{15}$ Annual Report of Professional Association of Tunisian Banks (2015), p.14.

${ }^{16}$ For more details, see appendix 2 relative to the correlation matrix.

Funding

There is no funding source. 
prepared the data base and selected and defined variables used in the empirical section. All authors read and approved the final manuscript.

\title{
Competing interests
}

The authors declare that they have no competing interests.

\section{Publisher's Note}

Springer Nature remains neutral with regard to jurisdictional claims in published maps and institutional affiliations.

\author{
Author details \\ ${ }^{1}$ Aix-Marseille University CERGAM (4225), Marseille, France. ${ }^{2}$ University of Jendouba, Faculty of Law, Economics and \\ Management of Jendouba, Jendouba, Tunisia.
}

Received: 5 May 2017 Accepted: 25 September 2017

Published online: 19 October 2017

\section{References}

Abreu M, Mendes V (2002) "Commercial Bank Interest Margins and Profitability: Evidence from E.U. Countries" University of Porto Working Paper $n^{\circ} 245$

Aggrawal, R, \& Jacques, K (2001) The impact of FDICIA and prompt corrective action on bank capital and risk: Estimates using a simultaneous equations model. J Bank Finance, 25, 1139-1160. https://doi.org/10.1016/S03784266(00)00125-4

Atasoy H (2007) Expenditure-Income Analysis in Turkish Banking Sector and Determinants of Profitability. In: Unpublished Dissertations of Senior Specialists. Central Bank of Turkey, Ankara

Athanasoglou, P Brissimis, S and Delis, M (2008) Bank-specific. industry-specific and macroeconomic determinants of bank profitability. J Int Financ Mark Inst Money 18 (2). 121-136. https://doi.org/10.1016/j.intfin.2006.07.001

Barros, CP, C Ferreira, and J Willians, (2007) Analysing the determinants of performance of best and worst European banks: a mixed logit approach J Bank Fin 31, 2189-2203 https://doi.org/10.1016/j.jbankfin.2006.11.010

Beck, T, Demirgüç-Kunt, A, \& Levine, R (2006). Bank concentration, competition, and crises: First results. J Bank Finance, 30, pp. 1581-1603. https://doi.org/10.1016/j.jbankfin.2005.05.010

Ben Naceur, S and Goaied, M, (2001) The determinants of the Tunisian deposit banks' performance, Appl Financ Econ, 131, pp, 17-19. https://doi.org/10.1080/096031001300138717

Ben Naceur S, Goaied M (2008) The Determinants of Commercial Bank Interest Margin and Profitability: Evidence from Tunisia. Frontiers, Finance and Econ 5(1):106-130

Berg, T, Saunders, A and Steffen, S (2013) The total cost of corporate borrowing in the loan market: Don't forget the fees, Working Paper

Berger AN, Bouwman CHS (2013) How does capital affect bank performance during financial crisis? J Financ Econ 109:146-176

Bourke, $\mathrm{P},(1989)$, Concentration and other determinants of bank profitability in Europe. North America and Australia, J Bank Finance, 13(1), pp, 65-79. https://doi.org/10.1016/0378-4266(89)90020-4

Boyd, JH, \& De Nicoló, G (2005) The theory of bank risk-taking and competition revisited. J Financ, 60, pp. 1329-1343. https://doi.org/10.1111/j.1540-6261.2005.00763.x

Carbó-Valverde S, Marqués-Ibá-ez D, Rodríguez-Fernández F (2011) Securitization, bank lending and credit quality: the case of Spain. Working Paper Series $N^{\circ} 1329$

Chiorazzo, V, Milani, C and Salvini, F, (2008) Income Diversification and Bank Performance: Evidence from Italian Banks J Financ Serv Res, 33, pp, 181-203. https://doi.org/10.1007/s10693-008-0029-4

Craigwell R, Maxwell C (2006) Non-interest income and financial performance at commercial banks in Barbados. Savings Dev 30(3):309-328

Cuong, Ly K (2015) Liquidity Risk, Regulation and Bank Performance: Evidence from European Banks. Global Econ Finance J, 8(1), pp. 11-33. https://doi.org/10.21102/gefj.2015.03.81.02

Delpachitra, S and Lester, L, (2013) Non-Interest Income: Are Australian Banks Moving Away from their Traditional Businesses? Econ Pap, 32 (2), pp, 190-199. https://doi.org/10.1111/1759-3441.12032

Demirgüç-Kunt, A and Huizinga, H, (1999) Determinants of Commercial Bank Interest Margins and Profitability: Some International Evidence World Bank Econ Rev, 13(2), pp, 379-408. https://doi.org/10.1093/wber/13.2.379

DeYoung, R and Roland, K, (2001a) Product Mix and Earnings Volatility at Commercial Banks: Evidence from a Degree of Total Leverage Model, J Financ Intermed, 10, pp, 54-84. https://doi.org/10.1006/fin.2000.0305

DeYoung R, and Roland K (2001b) Product Mix and Earnings Volatility at Commercial Banks: Evidence from a Degree of Leverage Model, J Financ Intermed, 31, pp. 54-84. https://doi.org/10.1006/fin.2000.0305

Ekpu V, Paloni A (2015) Financialisation, Business lending and profitability of the UK, Working paper № 2015-17

Froot KA, Stein JC (1998) Risk Management, Capital Budgeting and Capital Structure Policy for Financial Institutions: An Integrated Approach. J Financial Econ 47:55-82 https://doi.org/10.1016/S0304-405X(97)00037-8

García-Herrero, A Gavilá, S and Santabárbara, D, (2009) What explains the low profitability of Chinese banks? Journal of Banking and Finance 33 (11), pp, 2080-2092. https://doi.org/10.1016/j.jbankfin.2009.05.005

Graddy DB, Kyle, R, (1979) The Simultaneity of Bank Decision-Making, Market Structure and Bank Performance, J Financ 34, pp, 1-18. https://doi.org/10.1111/j.1540-6261.1979.tb02067.x

Hakimi A, Hamdi H, Djelassi M (2012) Modelling the non-interest income at Tunisian Banks. Asian Economics and Financial Review 1(2):88-99.

Hamdi H (2013) Testing Export-led Growth in Tunisia and Morocco: New Evidence using the Toda and Yamamoto procedure. Econ Bull 33(1):677-686. 
Hayden, E, Porath, D., and Westernhagen, N (2007) Does Diversification Improve the Performance of German Banks? Evidence from Individual Bank Loan Portfolios. J Financ Serv Res, 32, pp. 123-140. https://doi.org/10.1007/s10693-007-0017-0, https:// doi.org/10.1023/B:FINA.0000020657.59334.76

Ismail, A, Hanif, R, Choudhary, S and Ahmad, N, (2015) Income-diversification in banking sector of Pakistan: a 'Blessing' or 'Curse'?, J Commerce, Vol 7 N ํ1, pp.11-22

Jiang G, Tang N, Law E, Sze A (2003) Determinants of Bank Profitability in Hong Kong. Memorandum, Hong Kong Monetary Authority Research

Khalid Mndeme, R, (2015) Impact of non-interest income on banking performance in Tanzia. Int J Econ, Commerce Manage, Vol 3, N5, pp. 75-92

Landskroner, Y, Ruthenberg, D and Zaken, D, (2005) Diversification and performance in banking: The Israeli case. J Financ Serv Res, Vol 27, N¹, pp. 27-49. https://doi.org/10.1007/s10693-005-6411-6

Lee, C-C, Yang S-J, Chang, C-H, (2014) Non-interest income, profitability and risk in banking industry: A cross-country analysis, North Am J Econ Finance, Vol 27, pp 48- 67. https://doi.org/10.1016/j.najef.2013.11.002

Mamatzakis, E, \& Bermpei, T (2014) What drives investment bank performance? The role of risk, liquidity and fees prior to and during the crisis, Int Rev Financ Anal, 35, pp. 102-117. https://doi.org/10.1016/j.irfa.2014.07.012

Marozva, G, (2015), Liquidity and Bank Performance, Int Bus Econ Res J, Vol 14, №3, pp. 453-462. https://doi.org/10. 19030/iber.v14i3.9218

Meslier, C, Tacneng, R, and Tarazi, A, (2014) Is bank income diversification beneficial? Evidence from an emerging economy, J Int Financial Markets, Inst Money, Vol 31, pp. 97-126. https://doi.org/10.1016/j.intfin.2014.03.007

Molyneux, P, Remolona, E and Seth, R, (1998) Modeling Foreign Bank Performance and Lending Behavior, Financial Markets Inst Instrum, Vol7, N4, pp. 26-41. https://doi.org/10.1111/1468-0416.00022

Nguyen TC, Vo DV, Nguyen VC (2015) Risk and Income Diversification in the Vietnamese Banking System. J Appl Finance Bank 5(1):93-109.

Nilsen, J and Rovelli, R, (2001) Investor Risk Aversion \& Financial Fragility in Emerging Economies, J Int Financ Mark Inst Money, Vol 11, pp. 443-474. https://doi.org/10.1016/S1042-4431(01)00045-2

Pasiouras, F and Kosmidou, K, (2007) Factors influencing the profitability of domestic and foreign commercial banks in the European Union Res Int Bus Financ, Vol 21, No2, pp. 222-237. https://doi.org/10.1016/j.ribaf.2006.03.007

Pringle JJ, (1974) The Capital Decision in Commercial Banks, J Financ, Vol 29, №3, pp. 779-795. https://doi.org/10.1111/j. 1540-6261.1974.tb01483.x

Ramadan, I, Kilani, Q and Kaddumi, T, (2011) Determinants of bank profitability: Evidence from Jordan Int J Acad Res, Vol 3, № 4, pp. 180-191.

Saunders A, Schmid M, Walter I (2014) Non-Interest Income and Bank Performance : Is Banks' Increased Reliance on NonInterest Income Bad ? (No. 2014/17). Retrieved from http://ssrn.com/abstract=2504675, https://doi.org/10.2139/ssrn.2504675.

Schumpeter J (1912) The Theory of Economic Development: An Inquiry into Profits, Capital, Credit, Interest and the Business Cycle. Harvard University Press, Cambridge

Short B, (1979) The relation between commercial bank profit rates and banking concentration in Canada. Western Europe and Japan, J Bank Finance, Vol 3, No3, pp. 209-219. https://doi.org/10.1016/03784266(79)90016-5.

Soedarmono W, Machrouh F, Tarazi A, (2013) Bank competition, crisis and risk taking: Evidence from emerging markets in Asia, J Int Financial Markets Ins Money, Vol 23, pp. 196-221. https://doi.org/10.1016/j.intfin. 2012.09 .009

Stiroh KJ (2004a) Do community banks benefit from diversification? Journal of Financial Service. Research 25:135-160

Stiroh KJ (2004b) Diversification in banking: is non-interest income the answer? J Money Credit Bank, Vol 36, pp. 853882. https://doi.org/10.1353/mcb.2004.0076

Stiroh KJ (2006a) A Portfolio View of Banking with Interest and Noninterest Activities. J Money, Credit Bank 38(5):pp. ****. https://doi.org/10.1353/mcb.2006.0075

Stiroh KJ, (2006b) New Evidence on the Determinants of Bank Risk J Financ Serv Res, Vol 30, pp. 237-263. https://doi. org/10.1007/s10693-006-0418-5

Stiroh, KJ, Rumble, A (2006) The dark side of diversification: the case of U.S. financial holding companies. J Bank Finance, 30(8), pp. 2131-2161. https://doi.org/10.1016/j.jbankfin.2005.04.030

Sufian F and Shah Habibullah M (2010) Assessing the Impact of Financial Crisis on Bank Performance: Empirical Evidence from Indonesia, ASEAN Econ Bull,27(3), pp. 245-262. https://doi.org/10.1355/ae27-3a

Sun L, Wu S, Zhu Z, Stephenson A (2017) Noninterest Income and Performance of Commercial Banking in China, Sci Program, vol 2017, pp. 1-8. https://doi.org/10.1155/2017/3787053

Tan, A (2016) The impacts of risk and competition on bank profitability in China. J Int Financ Mark Inst Money, 40, pp. 85-110. https://doi.org/10.1016/j.intfin.2015.09.003

Tan, A and Anchor, J (2017) Does competition only impact on insolvency risk? New evidence from the Chinese banking industry. Int J Managerial Finance. Vol 13 (3), pp. 1-37. https://doi.org/10.1108/JMF-06-2016-0115

Tan, A, Floros, C and Anchor, J (2017) The Profitability of Chinese banks: impacts of risk, competition and efficiencyRev Account Finance, 16 (1), pp. 86-105. https://doi.org/https://doi.org/10.1108/RAF-05-2015-0072

Trivedi SR (2015) Banking Innovations and New Income Streams: Impact on Banks' Performance, J Decis Makers, Vol 40, Nº1, pp. 28-41. https://doi.org/https://doi.org/10.1177/0256090915573616

Williams, B and Prather, L, (2010) Bank risk and return: the impact of bank non-interest income Int J Managerial Finance, Vol 6, № 3, pp. 220-244. https://doi.org/https://doi.org/10.1108/17439131011056233 